Review

\title{
Benzoxetes and Benzothietes - Heterocyclic Analogues of Benzocyclobutene
}

\section{Herbert Meier}

Institute of Organic Chemistry, University of Mainz, Duesbergweg 10-14, D-55099 Mainz, Germany; E-Mail: hmeier@mail.uni-mainz.de; Tel.: +49-6131-392-2605; Fax: +49-6131-392-5396

Received: 7 December 2011; in revised form: 13 January 2012 / Accepted: 17 January 2012 /

Published: 7 February 2012

\begin{abstract}
Benzo-condensed four-ring heterocycles, such as benzoxetes $\mathbf{1}$ and benzothietes 3 represent multi-purpose starting compounds for the preparation of various higher heterocyclic ring systems. The thermal or photochemical valence isomerizations between the benzenoid forms 1,3 and the higher reactive $o$-quinoid structures 2,4 provide the basis for the synthetic applications. On the other hand, this valence isomerization impedes in particular the generation and storage of $\mathbf{1}$ because the thermal equilibrium $\mathbf{1} 2$ is completely on the side of 2 . Thus, the number of erroneous or questionable benzoxete structures published to date is surprisingly high. On the contrary, the thermal equilibrium $3 \rightleftarrows 4$ is on the side of the benzothietes 3 , which makes them easily accessible, especially by different flash vacuum pyrolysis techniques. The present article gives a survey of the preparations of $\mathbf{1}$ and 2, and tries to stimulate their use in synthetic projects. Naphtho-condensed and higher condensed compounds and compounds with an exocyclic $\mathrm{C}=\mathrm{O}$ or $\mathrm{S}=\mathrm{O}$ double bond (lactones, thiolactones, sulfoxides and sulfones) are not covered in this article.
\end{abstract}

Keywords: cycloaddition; flash-vacuum-pyrolysis; photochemistry; ring closure; ring opening

\section{Introduction}

$2 \mathrm{H}$-Benz $[b]$ oxetes (1) and $2 \mathrm{H}$-benzo[b]thietes (3), the heterocyclic analogues of benzocyclobutene (5) are highly interesting compounds because of their strained molecular structures which enables an easy thermal or photochemical ring opening to the o-quinoid valence isomers 2, 4 and 6 , respectively. The latter $8 \pi$ electron systems are reactive species which participate in a variety of addition and 
cycloaddition reactions. Figure 1 visualizes the thermal ring opening processes on the basis of ab initio calculations $\left(\mathrm{HF} / 6-31 \mathrm{G}^{* *}\right)[1]$.

Figure 1. $A b$ initio calculation of the valence isomerizations $1 \rightleftarrows 2(X=0), 3 \rightleftarrows 4(X=S)$ and $5 \rightleftarrows 6\left(\mathrm{X}=\mathrm{CH}_{2}\right)$. Energy differences in $\mathrm{kJmol}^{-1}[1]$.

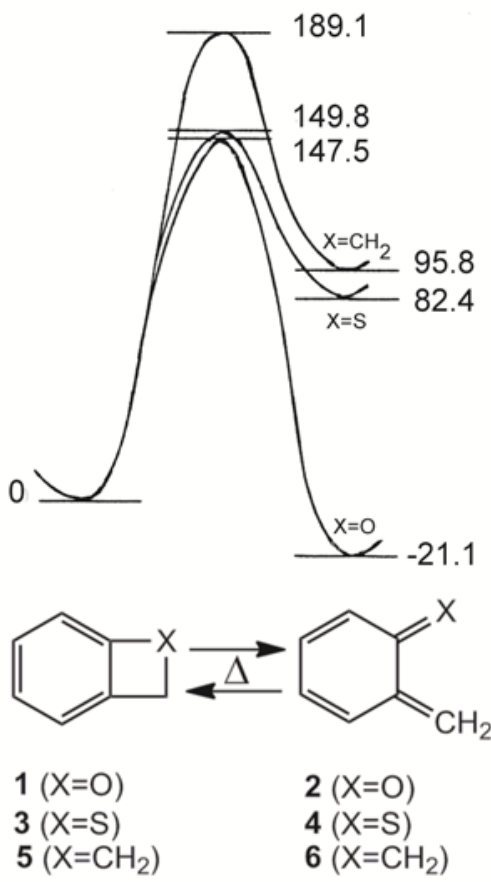

Early EHMO calculations revealed already an increasing tendency of the ring opening in the groundstate $\mathrm{S}_{0}$ as well as in the electronically excited singlet state $\mathrm{S}_{1}$ in the sequence $\mathrm{CH}_{2}<\mathrm{S}<\mathrm{O}$ [2] . Semiempirical quantum mechanics (MNDO) showed then that the ring opening $\mathbf{3} \rightarrow \mathbf{4}$ is an endothermic process [3] $—$ as in the carbocyclic case $\mathbf{5} \rightarrow \mathbf{6}$. The ring opening $\mathbf{1} \rightarrow \mathbf{2}$ however, is an exothermic reaction [4]:

\begin{tabular}{lrr} 
& $\mathbf{1}$ & $\mathbf{2}$ \\
$\Delta H_{\mathrm{f}}{ }^{\mathrm{MNDO}}\left(\mathrm{kJmol}^{-1}\right)$ & 76.1 & 38.5 \\
\hline$\Delta H_{\mathrm{f}}{ }^{\mathrm{MNDO}}\left(\mathrm{kJmol}^{-1}\right)$ & 172.2 & $\mathbf{3}$ \\
\end{tabular}

The corresponding enthalpy differences of -37.6 and $+79.9 \mathrm{kJmol}^{-1}$, respectively, agree very well to the results of earlier [1] or more recent $a b$ initio calculations $[5,6]$.

The thermal ring opening of benzoxetes 1 to o-quinone methides 2 can occur already far below room temperature, whereas benzothietes $\mathbf{3}$ are stable at ambient temperatures and isomerize to $o$-thioquinone methides 4 in toluene at about $100{ }^{\circ} \mathrm{C}\left(\Delta \mathrm{G}^{ \pm}=120.0 \mathrm{kJmol}^{-1}\right)$ [3]. The calculated activation barriers, shown in Figure 1, are somewhat too high. These features demonstrate the essential difference between $\mathbf{1}$ and $\mathbf{3}$ in synthetic applications: The benzoxetes $\mathbf{1}$ cannot normally be stored, and they or better their open valence isomers have to be freshly prepared and reacted in situ. The benzothietes 3 on the other hand, can be stored and can be opened thermally or photochemically whenever needed [3]. Another difference concerns the chemical behavior of $\mathbf{1} / \mathbf{2}$ and $\mathbf{3} / \mathbf{4}$ in the absence of reaction partners such as nucleophiles or dienophiles. $o$-Quinone methide 2 forms dimers, trimers 
and tetramers by repetitive Diels-Alder reactions [7-12]. Scheme 1 shows the $[2 \pi+4 \pi]$ - or better $[2 \pi+8 \pi]$ cycloadditions to the dimer 7. Apart from the exocyclic $\mathrm{CC}$ double bond, one of the endocyclic double bonds of 2 can also represent the $2 \pi$ component [12]. The hetero-Diels-Alder adduct $\mathbf{7}$ can enter then a further $[2 \pi+8 \pi]$ cycloaddition to yield the trimer $\mathbf{8}$, but $\mathbf{7}$ can also dimerize in a normal Diels-Alder reaction to the tetramer 9 [11].

Scheme 1. o-Quinone methide and its polycyclic oligomers.

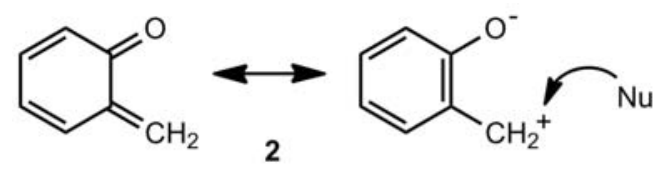<smiles>O=C1C=CC=CC12CCC1CC=CC=C1O2</smiles>

7<smiles>O=C1C=CC2Oc3ccccc3CC2C12CCc1ccccc1O2</smiles>

8<smiles>O=C1I=CC2C1C=CC(=O)C21CCc2ccccc2O1</smiles>

9

$o$-Thioquinone methide 4 behaves completely different (Scheme 2). It generates the [8 $+8 \pi]$ cyclodimer 10 and small amounts of higher cyclooligomers $(n=3-8)$ among which the cyclotrimer 11 and the cyclooctamer $\mathbf{1 1}$ are major components [3,9,13-15]; compounds $\mathbf{1 1}$ and 12 represent interesting thiocrown ethers.

Scheme 2. $o$-Thioquinone methide and its cyclooligomers.<smiles>C=C1C=CC=CC1=S</smiles>

10<smiles>[N+]=CC[C+]c1ccccc1[S-]</smiles><smiles>c1ccc(CSc2ccccc2CSc2ccccc2CSc2ccccc2)cc1</smiles>

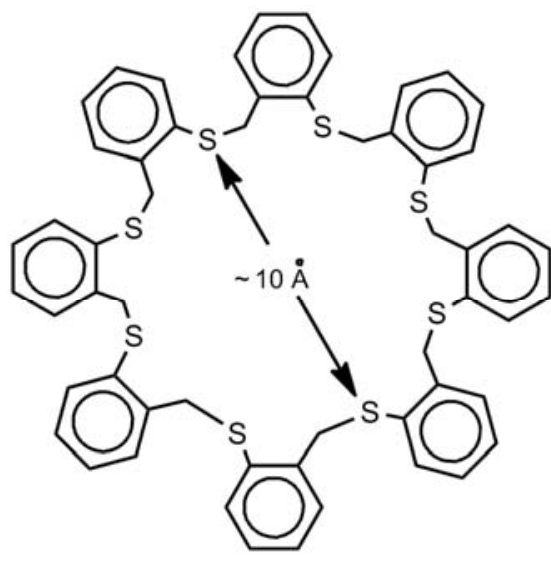

12

\section{Benzoxetes}

\subsection{Isolation of Benzoxetes}

The first isolable benzoxetes were obtained by Adam et al. [12,16]. Scheme 3 demonstrates the mode of preparation. Low temperature oxidations of benzofurans 13a-o by dimethyldioxirane afford mixtures of the epoxides 14a-o and the o-quinone methides 15a-o in high yields. The ratio of the 14/15 equilibrium depends on the substituents varying from almost pure 14f to almost pure 15h. All 
these trienediones 15 have $(Z)$-configurations. Irradiation $(\lambda=589 \mathrm{~nm})$ of the $\mathbf{1 4 / 1 5}$ mixtures between -25 and $-78{ }^{\circ} \mathrm{C}$ yields then in most cases the desired benzoxetes (conversion $\geq 95 \%$ ). Exceptions are the systems $\mathbf{1 4 / 1 5 b , f , k , l}\left(\mathrm{R}^{1} \neq \mathrm{H}\right)$. Low-temperature irradiations are necessary because the $o$-quinone methides 15 can isomerize above $0{ }^{\circ} \mathrm{C}$ by $1.5-\mathrm{H}$ shifts to phenols [12]. Moreover, the benzoxetes 16 revert thermally to the valence isomers $14 / 15$. The $\mathrm{Cl}$-containing compounds $\mathbf{1 6 m}-\mathbf{0}$ exist at $-10{ }^{\circ} \mathrm{C}$ for approximately $1 \mathrm{~h}$, the $\mathrm{OCH}_{3}$ systems $\mathbf{1 6 g}-\mathbf{i}$ are even more labile. The resulting $o$-quinone methides can then oligomerize, as discussed above. In the presence of enol ethers, compounds 15 yield 3,4-dihydro- $2 H$-benzopyrans, as the example 17a reveals, and in the presence of methanol a tautomeric mixture of the hydroxyketones $\mathbf{1 8}$ and their hemiacetals $\mathbf{1 9}$ is obtained [12].

Scheme 3. The first successful approach to benzoxetes.<smiles>[R]c1c([R])c([R1])c2c(C)c(C)oc2c1[R1]</smiles>

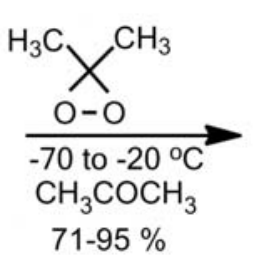

$71-95 \%$

$13 a-0$<smiles>[R]c1c([R])c([R])c2c(c1[R])OC1(C)OC21C</smiles>

14a-o<smiles>[R]C1=C([R])C([R])=C([R])C(=C(C)C(C)=O)C1=O</smiles>

15a-o

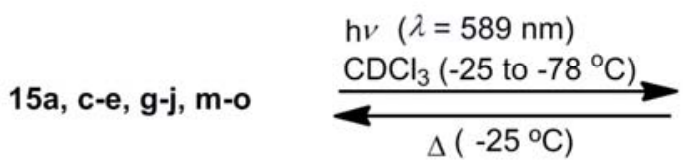<smiles>[R]C1=C([R])C([R7])C2=C1C(C)(C(C)=O)O2</smiles>

16a, c-e, g-j, m-o (82-95\%)<smiles>[R]c1c([R])c([R])c2c(c1[R])OC(OC)CC2(C)C(C)=O</smiles>

$17 a\left(R^{i}=H\right)$

(94\% from 15a)<smiles>[R]c1c([R])c([R])c2c(c1[R])OC(C)(O)C2(C)OC</smiles>

18

19

\begin{tabular}{lllllllllllllll}
$\mathbf{a}$ & $\mathbf{b}$ & $\mathbf{c}$ & $\mathbf{d}$ & $\mathbf{e}$ & $\mathbf{f}$ & $\mathbf{g}$ & $\mathbf{h}$ & $\mathbf{i}$ & $\mathbf{j}$ & $\mathbf{k}$ & $\mathbf{l}$ & $\mathbf{m}$ & $\mathbf{n}$ & $\mathbf{o}$ \\
\hline $\mathrm{R}^{1} \mathrm{H}$ & $\mathrm{CH}_{3}$ & $\mathrm{H}$ & $\mathrm{H}$ & $\mathrm{H}$ & $\mathrm{OCH}_{3}$ & $\mathrm{H}$ & $\mathrm{H}$ & $\mathrm{H}$ & $\mathrm{H}$ & $t-\mathrm{Bu}$ & $\mathrm{Cl}$ & $\mathrm{H}$ & $\mathrm{H}$ & $\mathrm{H}$ \\
$\mathrm{R}^{2} \mathrm{H}$ & $\mathrm{H}$ & $\mathrm{CH}_{3}$ & $\mathrm{H}$ & $\mathrm{H}$ & $\mathrm{H}$ & $\mathrm{OCH}_{3}$ & $\mathrm{H}$ & $\mathrm{H}$ & $t-\mathrm{Bu}$ & $\mathrm{H}$ & $\mathrm{H}$ & $\mathrm{Cl}$ & $\mathrm{H}$ & $\mathrm{H}$ \\
$\mathrm{R}^{3} \mathrm{H}$ & $\mathrm{H}$ & $\mathrm{H}$ & $\mathrm{CH}_{3}$ & $\mathrm{H}$ & $\mathrm{H}$ & $\mathrm{H}$ & $\mathrm{OCH}_{3}$ & $\mathrm{H}$ & $\mathrm{H}$ & $t-\mathrm{Bu}$ & $\mathrm{H}$ & $\mathrm{H}$ & $\mathrm{Cl}$ & $\mathrm{H}$ \\
$\mathrm{R}^{4} \mathrm{H}$ & $\mathrm{H}$ & $\mathrm{H}$ & $\mathrm{H}$ & $\mathrm{CH}_{3}$ & $\mathrm{H}$ & $\mathrm{H}$ & $\mathrm{H}$ & $\mathrm{OCH}_{3}$ & $\mathrm{H}$ & $\mathrm{H}$ & $\mathrm{H}$ & $\mathrm{H}$ & $\mathrm{H}$ & $\mathrm{Cl}$
\end{tabular}

The benzoxetes 16 were characterized by their ${ }^{1} \mathrm{H}$ - and ${ }^{13} \mathrm{C}-\mathrm{NMR}$ spectra at low temperatures. The quaternary carbon atoms of the oxete ring show typical ${ }^{13} \mathrm{C}$ chemical shifts: $\delta(\mathrm{C}-2)=102 \pm 2$, $\delta(\mathrm{C}-2 \mathrm{a})=132 \pm 3$ and $\delta(\mathrm{C}-6 \mathrm{a})=162 \pm 3 \mathrm{ppm}[12,16]$.

Recently a Chinese research group [17] reported the isolation of a 5-aryl-2-hydroxybenzoxete 20 from the stem of Caesalpinia decapetala (Figure 2). Although the structure was carefully studied by NMR including HMBC measurements, the stability of $\mathbf{2 0}$ raises some doubts about the validity of the proposed structure [18-20]. 
Figure 2. A natural product, for which a benzoxete structure was postulated.

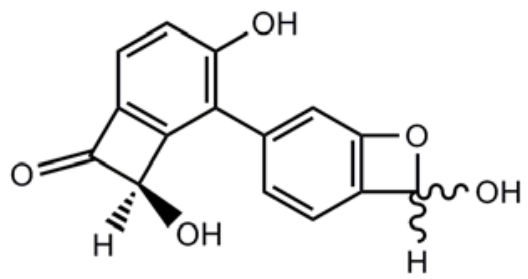

20

\subsection{Matrix Isolation of Benzoxetes}

Unsubstituted benzoxete 1, the parent compound, was first obtained by Tomioka et al. (Scheme 4) [1,21]. The masked diazo compound 21, developed by Eschenmoser [22], was used to produce the carbene 23 via the diazo system 22 at $10 \mathrm{~K}$ in an Ar matrix. The IR spectra revealed the formation of o-quinone methide (2) together with its valence isomer, benzoxete 1. Benzofuranone 24 provides another successful entry to the wavelength-dependent ratio $\mathbf{1} / \mathbf{2}$.

Scheme 4. Generation of unsubstituted benzoxete.

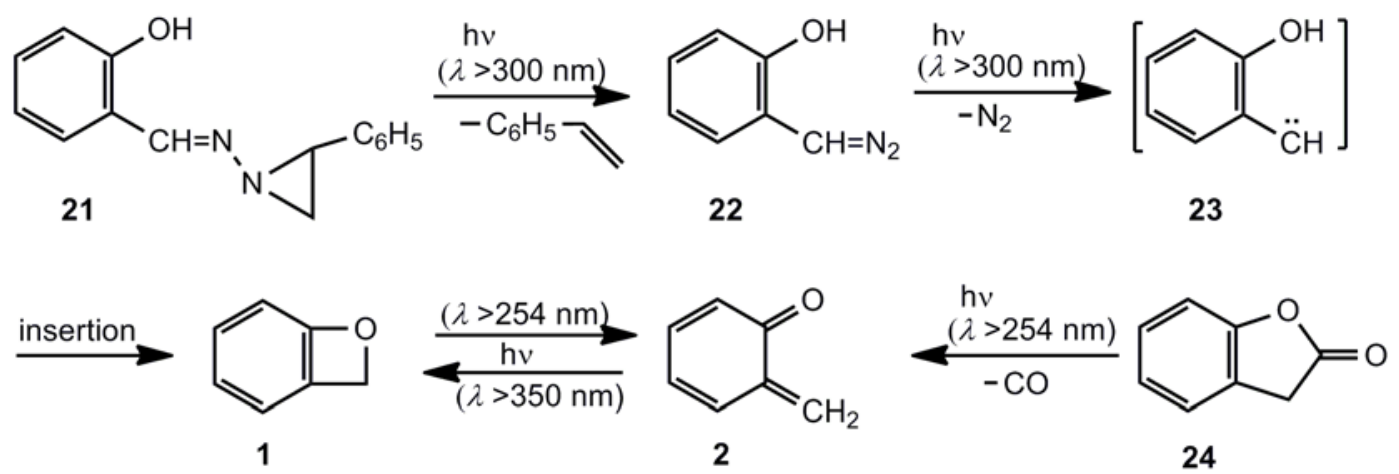

Chapman et al. [23] studied the cyclic diazo compound 25 (Scheme 5). According to IR and UV measurements, irradiation at $8 \mathrm{~K}$ in an Ar matrix generated carbene 26, which formed 27 and its photoproduct 28 [23,24]. The 27/28 ratio depends on the wavelength applied; however, an extended irradiation at $254 \mathrm{~nm}$ yields the 1,2-didehydrobenzene 29. Irradiation of $\mathbf{2 5}$ in methanol at ambient temperatures furnishes the ester 30 [25] and irradiation in acidic aqueous solutions gives the corresponding carboxylic acid and 3-hydroxy-3H-benzofuran-2-one [24]. In hexane, the intermediate primary photoproduct 27 dimerizes to isoxindigo 31, small amounts of bislactone 32 and coumestan 33, the decarbonylated product [24].

Wentrup et al. [8] generated the equilibrium mixture of $\mathbf{1}$ and 2 by flash-vacuum-pyrolysis (FVP) of benzofuran-2-one (24) or 2-(hydroxymethyl)phenol followed by the photochemical cyclization $\mathbf{2} \rightarrow \mathbf{1}$. Warm-up experiments demonstrated that benzoxete $\mathbf{1}$ is stable up to at least $155 \mathrm{~K}$. Surprisingly, methyl substituents on the benzene ring stabilize the benzoxete system 36 significantly (Scheme 6). 
Scheme 5. Photolysis of 3-diazo-2(3H)-benzofuranone.

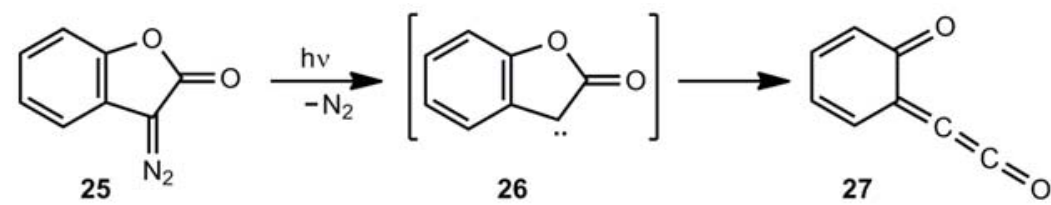

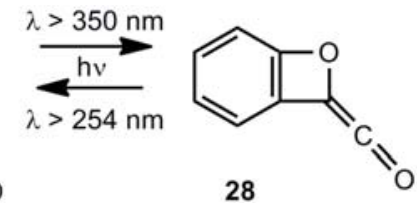<smiles>COC(=O)C(OC)c1ccccc1O</smiles>

31<smiles>O=c1oc2ccccc2c2c(=O)oc3ccccc3c12</smiles>

32

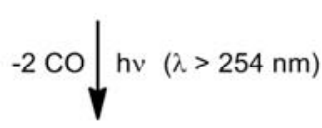<smiles>c1ccccc1</smiles>

29

Scheme 6. Generation of 4,6-dimethylbenzoxete.<smiles>Cc1cc(C)c(O)c(CO)c1</smiles>

34

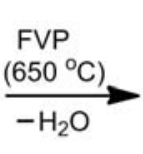

$-\mathrm{H}_{2} \mathrm{O}$<smiles>C=C1C=C(C)C=C(C)C1=O</smiles>

35

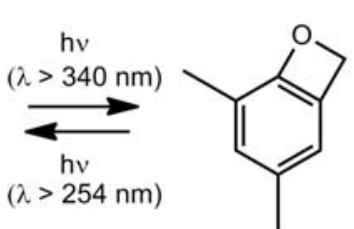

36

4,6-Dimethylbenzoxete (36), obtained at $7.6 \mathrm{~K}$ in an $\mathrm{Ar}$ matrix, was characterized by IR spectroscopy. In the presence of water, the dihydroxy compound $\mathbf{3 4}$ is recovered, in the absence of nucleophiles dimer 37, trimer 38 and tetramer 39 (Scheme 7) are obtained [8].

Scheme 7. Polycyclic oligomers of 4,6-dimethylbenzoxete.

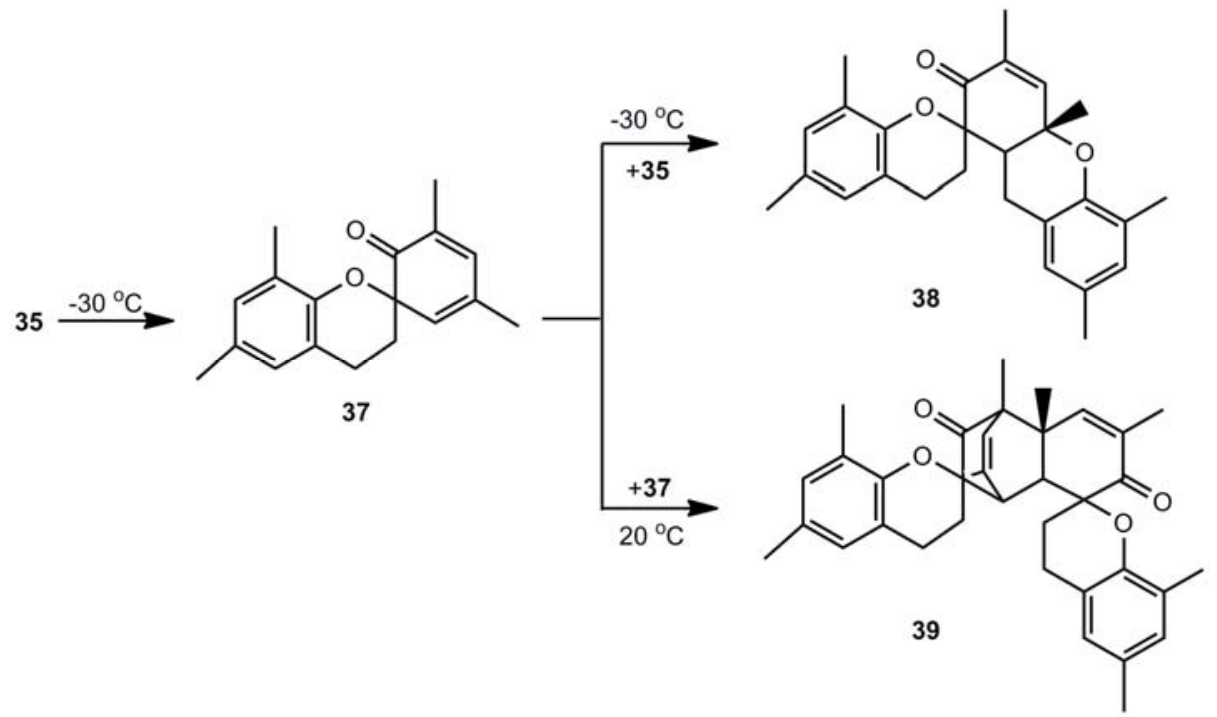


Trimer 38, subjected to FVP at $850{ }^{\circ} \mathrm{C}$, is a good precursor for 0 -quinone methide 35 . The dehydration of 2-hydroxymethylphenols by FVP, shown in Scheme 6, can also be achieved by irradiation [5].

\subsection{Benzoxetes as Intermediates}

Benzoxetes can be intermediates in various reactions. A quite new example is shown in Scheme 8 [26,27]. Benzyne or other arynes react with $N, N$-dialkylformamides or $N, N$ dialkylacetamides. Treatment of $\mathbf{4 0}$ with tributylammonium or cesium fluoride in acetonitrile generates the arynes 41, which undergo with carboxylic acid amides [2+2] cycloadditions to the benzoxetes 42. Their corresponding $\boldsymbol{o}$-quinone methides $\mathbf{4 3}$ can be trapped by water to afford $\mathbf{4 4}$ [26], or with zinc organic compounds to form 45 [27], or by reactive methylene components to generate 46 [26] and

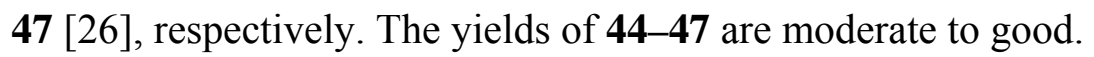

Scheme 8. Benzoxetes as intermediate in the reaction of arynes and carboxamides.
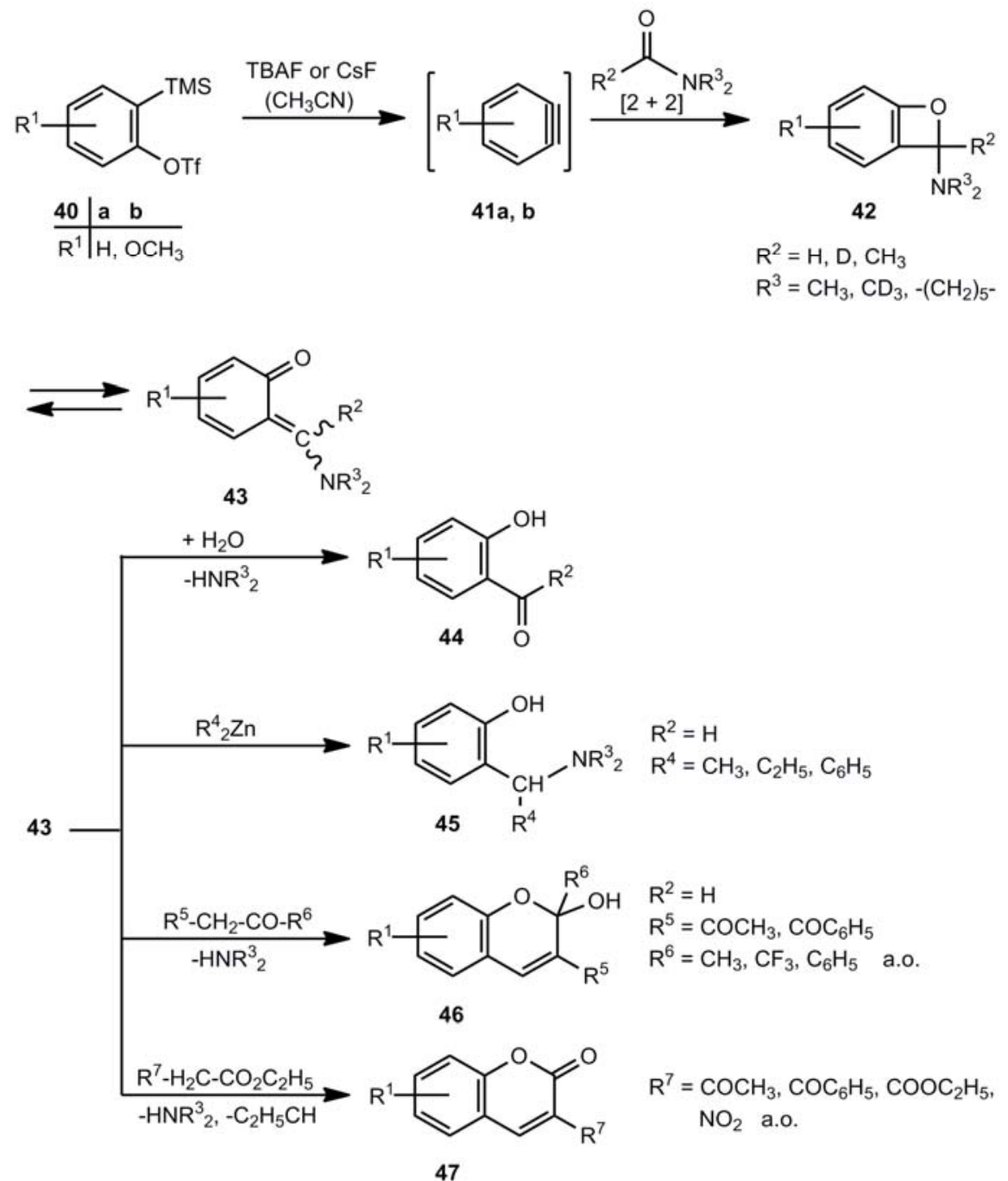

A related [2+2] cycloaddition was already found in the early seventies [28,29]. The dehydrobenzene 48 reacted with $\alpha, \beta$-unsaturated aldehydes, such as cinnamaldehyde (49), to yield 5,6,7,8tetrachloroflav-3-ene (52) via the benzoxete 50 and its valence isomer 51 (Scheme 9). 
Scheme 9. 3,4,5,6-Tetrachloro-2-styrylbenzoxete as intermediate in the reaction of an aryne and cinnamaldehyde.<smiles>Clc1cccc(Cl)c1Cl</smiles>

48

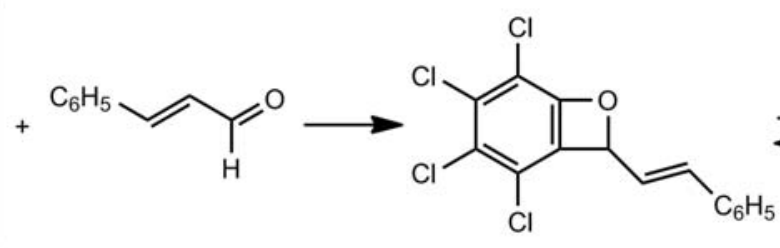

49

50<smiles>CCC/C=C\C=C1/C(=O)C(Cl)=C(Cl)C(Cl)=C1Cl</smiles>

51

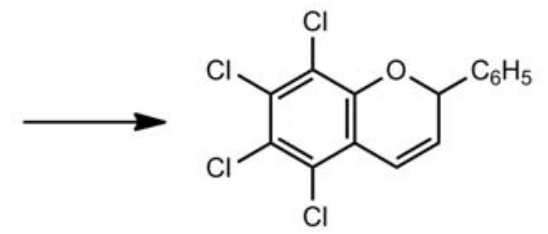

According to UV reaction spectra of the photolysis of dibenzo[1,4]dioxins 53, the spiro compounds 54 were postulated as intermediates on the route to the 2,2'-biphenylquinones 55 (Scheme 10). The initial aryl ether cleavage $\mathbf{5 3} \rightarrow \mathbf{5 4}$ is followed at room temperature by the thermal valence isomerization to $\mathbf{5 5}$. Under steady-state irradiation conditions, the quinones $\mathbf{5 5}$ undergo in the excited state a hydrogen abstraction from the solvent. Thus, the 2,2'-dihydroxybiphenyls $\mathbf{5 6}$ are generated in reasonable yields [30].

Scheme 10. Photolysis of dibenzo[1,4]dioxins.<smiles>[R]c1c([R])c([R])c2c(c1[R])OC1(O2)Oc2c([R])c([R])c([R])c([R])c21</smiles><smiles>C[C@@H]1CCN1C</smiles>

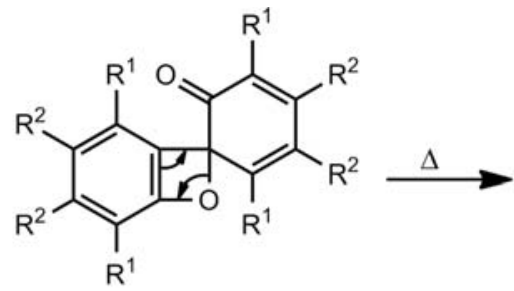

$$
\begin{array}{l|lllll} 
& \mathbf{a} & \mathbf{b} & \mathbf{c} & \mathbf{d} & \mathbf{e} \\
\hline \mathrm{R}^{1} & \mathrm{H} & \mathrm{H} & \mathrm{H} & \mathrm{H} & \mathrm{Cl} \\
\mathrm{R}^{2} & \mathrm{H} & \mathrm{CH}_{3} & \mathrm{Cl} & \mathrm{OCH}_{3} & \mathrm{Cl}
\end{array}
$$

54a-e<smiles>[R]C1=C([R])C([R])=C([R])C(=C2C(=O)C([R])=C([R])C([R])=C2[R])C1=O</smiles>

(E)-55a-e<smiles>[R]c1c([R])c([R])c(-c2c([R])c([R])c([R])c([R])c2O)c([R7])c1[R]</smiles>

56a-e

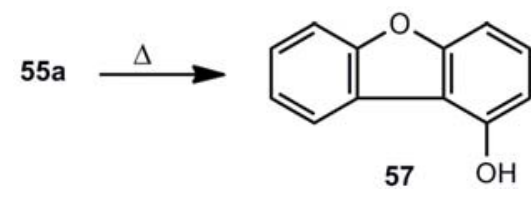<smiles>[R]C1=COc2oc3cc([R])c([R])cc3c2C=C1[R]</smiles> 
In the dark, 55a and 2,2'-biphenylquinones with electron-withdrawing substitutents rearrange to 1-hydroxydibenzofurans 57, whereas the 2,2'-biphenylquinones $\mathbf{5 5 b , d}$ with electron-releasing substituents form oxepino[2,3-b]benzofurans (58) [30].

\subsection{Erroneous Benzoxete Structures}

Apart from the photochemically generated spiro compounds 54a-e, many spiro[2,4cyclohexadiene-1,8'-[7] oxabicyclo[4.2.0] octa-(1,3,5)-trien]-6-ones 54'f-o [31-45] and 54'p,q [34] (Table 1) have been postulated as thermal reaction products. Table 1 provides a survey over these sterically hindered systems, whose benzoxete structures were proved to be wrong.

Table 1. Erroneous benzoxete structures 54' and 54".<smiles>[R]C1=C([R])C([R])C2(Oc3c([R])c([R])c([R])c([R])c32)C([R])=C1[R]</smiles>

\begin{tabular}{cccccccccc}
\hline Compound & $\mathbf{R}^{\mathbf{1}}$ & $\mathbf{R}^{\mathbf{2}}$ & $\mathbf{R}^{\mathbf{3}}$ & $\mathbf{R}^{\mathbf{4}}$ & $\mathbf{R}^{\mathbf{5}}$ & $\mathbf{R}^{\mathbf{6}}$ & $\mathbf{R}^{\mathbf{7}}$ & $\mathbf{R}^{\mathbf{8}}$ & References \\
\hline $\mathbf{5 4} \mathbf{f}$ & $t-\mathrm{Bu}$ & $\mathrm{H}$ & $t-\mathrm{Bu}$ & $\mathrm{H}$ & $t-\mathrm{Bu}$ & $\mathrm{H}$ & $t-\mathrm{Bu}$ & $\mathrm{H}$ & {$[31,36,37,39,42-44,47]$} \\
$\mathbf{5 4}^{\prime} \mathbf{g}$ & $t-\mathrm{Bu}$ & $\mathrm{H}$ & $\mathrm{OMe}$ & $\mathrm{H}$ & $t-\mathrm{Bu}$ & $\mathrm{H}$ & $\mathrm{OMe}$ & $\mathrm{H}$ & {$[32-34,46,47]$} \\
$\mathbf{5 4}^{\prime} \mathbf{h}$ & $t-\mathrm{Bu}$ & $\mathrm{H}$ & $\mathrm{CMe}_{2} \mathrm{Et}$ & $\mathrm{H}$ & $t-\mathrm{Bu}$ & $\mathrm{H}$ & $\mathrm{CMe}{ }_{2} \mathrm{Et}$ & $\mathrm{H}$ & {$[35]$} \\
$\mathbf{5 4}^{\prime} \mathbf{i}$ & $\mathrm{CMe}_{2} \mathrm{Et}$ & $\mathrm{H}$ & $t-\mathrm{Bu}$ & $\mathrm{H}$ & $\mathrm{CMe}_{2} \mathrm{Et}$ & $\mathrm{H}$ & $t-\mathrm{Bu}$ & $\mathrm{H}$ & {$[35]$} \\
$\mathbf{5 4}^{\prime} \mathbf{j}$ & $\mathrm{CMe} 2 \mathrm{Et}$ & $\mathrm{H}$ & $\mathrm{CMe}_{2} \mathrm{Et}$ & $\mathrm{H}$ & $\mathrm{CMe}_{2} \mathrm{Et}$ & $\mathrm{H}$ & $\mathrm{CMe}_{2} \mathrm{Et}$ & $\mathrm{H}$ & {$[36,40,42,47]$} \\
$\mathbf{5 4}^{\prime} \mathbf{k}$ & $t-\mathrm{Bu}$ & $\mathrm{H}$ & $\mathrm{CPh}_{3}$ & $\mathrm{H}$ & $t-\mathrm{Bu}$ & $\mathrm{H}$ & $\mathrm{CPh}_{3}$ & $\mathrm{H}$ & {$[41,42,47]$} \\
$\mathbf{5 4}^{\prime} \mathbf{l}$ & $t-\mathrm{Bu}$ & $\mathrm{H}$ & $\mathrm{OC}_{6} \mathrm{H}_{4}-$ & $\mathrm{H}$ & $t-\mathrm{Bu}$ & $\mathrm{H}$ & $\mathrm{OC}_{6} \mathrm{H}_{4}-$ & $\mathrm{H}$ & {$[38]$} \\
$\mathbf{5 4}^{\prime} \mathbf{m}$ & $t-\mathrm{Bu}$ & $\mathrm{H}$ & $\mathrm{COOEt}^{\prime}$ & $\mathrm{Me}$ & $t-\mathrm{Bu}$ & $\mathrm{H}$ & $\mathrm{COOEt}$ & $\mathrm{Me}$ & {$[45,47]$} \\
$\mathbf{5 4}^{\prime} \mathbf{n}$ & $t-\mathrm{Bu}$ & $\mathrm{H}$ & $t-\mathrm{Bu}$ & $\mathrm{Cl}$ & $t-\mathrm{Bu}$ & $\mathrm{H}$ & $t-\mathrm{Bu}$ & $\mathrm{Cl}$ & {$[45,47]$} \\
$\mathbf{5 4}^{\prime} \mathbf{o}$ & $t-\mathrm{Bu}$ & $\mathrm{Cl}$ & $t-\mathrm{Bu}$ & $\mathrm{Cl}$ & $t-\mathrm{Bu}$ & $\mathrm{Cl}$ & $t-\mathrm{Bu}$ & $\mathrm{Cl}$ & {$[45,47]$} \\
$\mathbf{5 4}^{\prime \prime} \mathbf{p}$ & $t-\mathrm{Bu}$ & $\mathrm{H}$ & $\mathrm{OMe}$ & $\mathrm{H}$ & $t-\mathrm{Bu}$ & $\mathrm{H}$ & $\mathrm{OMe}$ & $\mathrm{OMe}$ & {$[34,49]$} \\
$\mathbf{5 4}^{\prime \prime} \mathbf{q}$ & $t-\mathrm{Bu}$ & $\mathrm{H}$ & $\mathrm{OMe}$ & $\mathrm{H}$ & $t-\mathrm{Bu}$ & $\mathrm{H}$ & $\mathrm{OMe}$ & $\mathrm{OEt}$ & {$[34,49]$} \\
\hline
\end{tabular}

The oxidation of phenols or biphenols leads to 2,2'-biphenylquinones 55 (Scheme 11) for which three types of electrocyclic ring closure reactions can be conceived. The formation of dibenzo[c,e][1,2]dioxins 59 [46] was discounted and the generation of sterically hindered benzoxetes 54'f-o claimed [31-46]. However, it turned out on the basis of NMR studies and a crystal structure analysis of $\mathbf{5 8 0}$ [47,48], that the real structures of $\mathbf{5 4}$ ' $\mathbf{f}-\mathbf{0}$ are oxepino[2,3-b]benzofurans $\mathbf{5 8 f}-\mathbf{0}[47,48]$.

In contrast to the photochemical generation shown in Scheme 10, there is no thermal route $55 \rightarrow \mathbf{5 4}$ '. The compounds 54"p,q are reaction products of 54' $\mathbf{g}$ and have the structures 60p,q [48] (Figure 3).

Out of a series of older references [50-57] on alleged benzoxetes, just one shall be discussed here, namely the work of Mastagli et al. [54], which provides an interesting polycyclic system 64 instead of a threefold benzoxete (63) (Scheme12). The reaction of salicylic aldehyde (61) and formamide (62) yields the ring system 64, a tribenzotrioxaazaphenalene [58]. 
Scheme 11. Valence isomers of 2,2'-biphenylquinones.

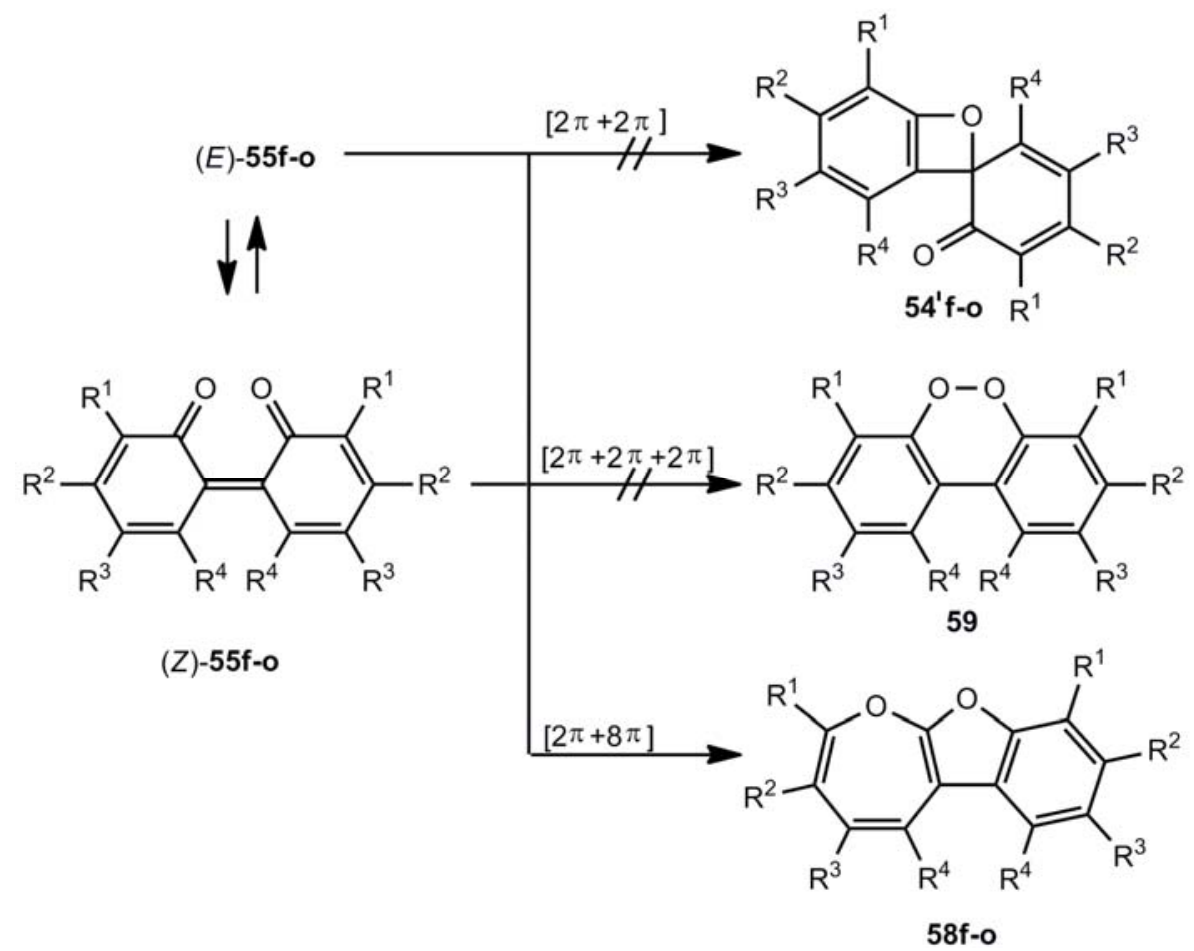

Figure 3. 1(4H)-Dibenzofuranones.<smiles>[R]O[C@H](OC)[C@@]1([R])C=C(C)C(=O)c2c1oc1c(C(C)(C)C)cc(OC)cc21</smiles>

Scheme 12. Reaction of salicylic aldehyde and formamide.

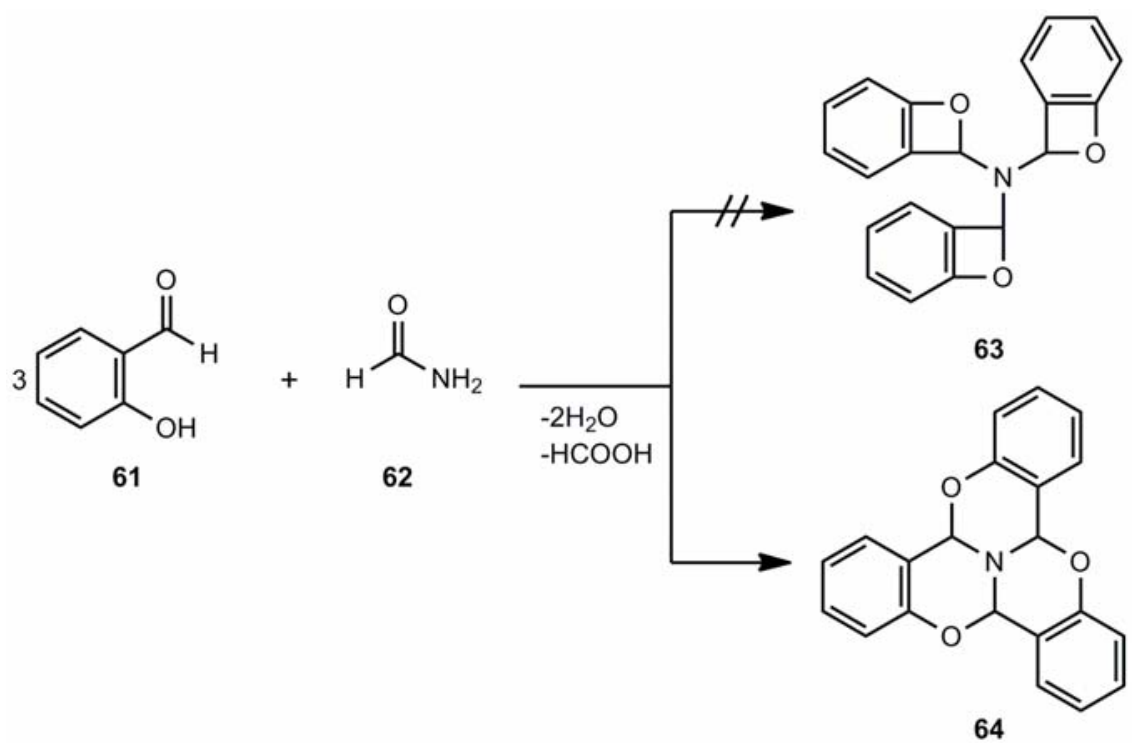




\section{Benzothietes}

\subsection{Preparation of Benzothietes by Ring Contraction Reactions}

The first successful synthesis of benzothietes was published in 1976 by Meier et al. The Wolff rearrangement of 3-diazobenzo[b]thiophen-2(3H)-one $(65)$ yields the ketene $\mathbf{6 6}$ and in the presence of alcohols the corresponding esters 67a-c (Scheme 13) [59,60].

Scheme 13. Photochemical Wolff rearrangement of 3-diazobenzo[b]thiophen-2(3H)-one.

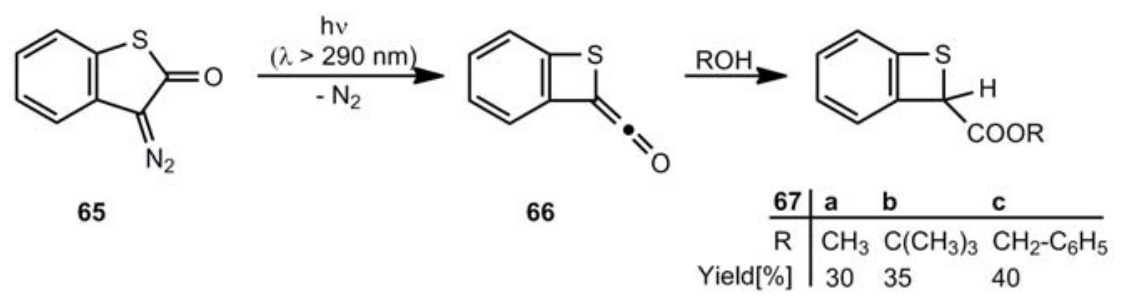

A kind of Favorsky rearrangement can be used for the ring contraction of the hexachloro compound 68 to afford the benzothiete derivative 69 (Scheme 14) [61].

Scheme 14. Ring contraction of perchlorobenzo[b]thiophen-2(3H)-one.<smiles>O=C1Sc2c(Cl)c(Cl)c(Cl)c(Cl)c2C1(Cl)Cl</smiles>

68

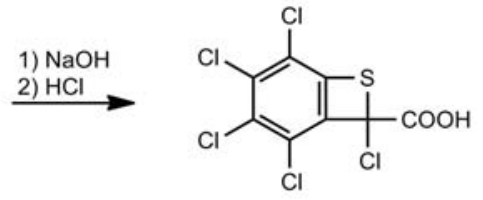

69

\subsection{Benzothietes by Cycloelimination Reactions}

Several cycloelimination reactions of $\mathrm{CO}, \mathrm{CO}_{2}$ or $\mathrm{SO}_{2}$ can be applied for the generation of benzothiete (Scheme 15). The parent compound 3 could be originally obtained by a multi-step degradation of $\mathbf{6 7 b}[3,59]$, but each of the elimination routes a)-c), shown in Scheme 15, provides a much easier route.

Scheme 15. Thermal or photochemical cycloelimination reactions leading to benzothiete.

a)

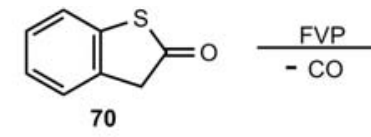

b)<smiles>O=C1OCc2ccccc2S1</smiles><smiles></smiles>

c)<smiles>O=S1(=O)C=Cc2ccccc21</smiles><smiles>[R17]1CCCCC1</smiles><smiles>C=C1C=CC=CC1=S</smiles><smiles>C(=CC1CC1)c1ccc2c(c1)CS2</smiles>

d)<smiles></smiles> 
The decarbonylation of $\mathbf{7 0}$ by flash-vacuum-pyrolysis (FVP) [14,62] and the decarboxylation of 71 by thermolysis in solution or FVP $[63,64]$ look straightforward. Interestingly, the sulfone 72 does not eliminate $\mathrm{SO}_{2}$, and after a rearrangement $\mathrm{CO}_{2}$ is split off $[65,66]$. In cold traps, 3 can be isolated in all these cases in yields up to $90 \%$. The photodesulfonylation of 73 in benzene however, can only be used for trapping reactions of $o$-thiobenzoquinone methide 4 [67]. Substituted benzothietes (Scheme 16) can be obtained in high yields by FVP of the corresponding benzoxathiinones 71 [64].

Scheme 16. Preparation of substituted benzothietes by flash-vacuum-pyrolysis.<smiles>[R]c1cc([R2])c2c(c1)SC(=O)OC2</smiles>

71a-d<smiles>[R]c1cc([R])c2c(c1)SC2</smiles>

$74 a-d$

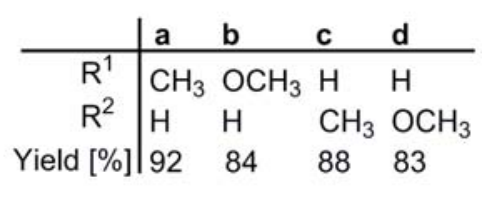

\subsection{Benzothietes by Cyclization Reactions}

Boekelheide et al. [9] developed the preparation of benzothiete (3) by FVP of 2-mercaptobenzyl alcohol (75) (Scheme 17).

Scheme 17. Preparation of unsubstituted benzothiete by flash-vacuum-pyrolysis of 2-mercaptobenzyl alcohol.<smiles>OCc1ccccc1S</smiles>

75

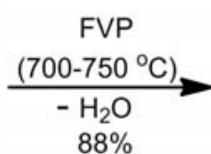<smiles>C=C1C=CC=CC1=S</smiles>

4

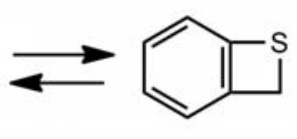

3

Fifty g of 3 per hour can be obtained in a suitable flow device [3]. Side products are not formed and the amount of unreacted starting material can be reduced by increasing the contact time [68]. Instead of the hydroxyl compound, o-chloromethylthiophenol can be used, too [3].

Another 1,4-elimination was studied with benzene sulfenic acid 77, an intermediate in the FVP of 76 (Scheme 18). The elimination of $\mathrm{H}_{2} \mathrm{O}$ can occur with the methylene group or with one of the methyl groups. Therefore, benzothiete $\mathbf{7 8}$ and benzo[b]thiopyran $\mathbf{7 9}$ are obtained [69].

An unusual cyclization reaction was observed for 2,4,6-tris(trifluoromethyl)thiophenol [70]. The threefold elimination of HF led to benzothiete 81, whose structure was confirmed by a crystal structure analysis (Scheme 19). The reaction was performed in the presence of $\mathrm{Ga}\left(\mathrm{CH}_{3}\right)_{3}$, whose role is not established.

A series of spiro-compounds 82 and 83 were reported as reaction products of 2-chlorobenzaldehydes, $\alpha, \omega$-diamines and sulfur [71,72]. However, since the corresponding benzoxetes [50] certainly have different structures, a reinvestigation of $\mathbf{8 2}$ and $\mathbf{8 3}$ seems to be advisable. The same is true for the compounds 84 [73-75] (Figure 4). 
Scheme 18. Flash-vacuum-pyrolysis of 2-butylsulfonyl-1,3,5-tris(2,2-dimethylpropyl)benzene.<smiles>CCCCS(=O)c1c(CC(C)(C)C)cc(CC(C)(C)C)cc1CC(C)(C)C</smiles><smiles>CCc1cc(CC(C)(C)C)c(SO)c(C(C)(C)C)c1</smiles><smiles></smiles><smiles>CC(C)(C)Cc1cc(CC(C)(C)C)c2c(c1)CC(C)(C)CS2</smiles>

$79(25 \%)$

Scheme 19. Elimination of hydrogen fluoride for the preparation of a highly substituted benzothiete.<smiles>FC(F)(F)c1cc(C(F)(F)F)c(S)c(C(F)(F)F)c1</smiles>

80<smiles>FC(F)(F)c1cc(C(F)(F)F)c(SC2(Sc3c(C(F)(F)F)cc(C(F)(F)F)cc3C(F)(F)F)Sc3c(C(F)(F)F)cc(C(F)(F)F)cc32)c(C(F)(F)F)c1</smiles>

81

Figure 4. Postulated benzothietes with amino substituents.

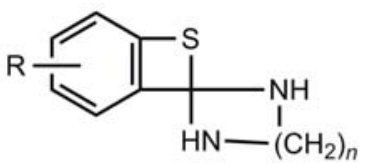

82<smiles>[R][R]1ccc2c(c1)C(N([R])C1Sc3ccccc31)S2</smiles>

84<smiles></smiles>

83

$$
\mathrm{R}=\mathrm{H}, \mathrm{Cl}, \mathrm{CH}_{3}
$$$$
n=2,3
$$

$\mathrm{R}^{1}=\mathrm{CO}-\mathrm{CH}_{3},\left(\mathrm{CH}_{2}\right)_{2}-\mathrm{OH}, \mathrm{C}_{6} \mathrm{H}_{11}, \mathrm{C}_{6} \mathrm{H}_{5}$, $\mathrm{C}_{6} \mathrm{H}_{4}-\mathrm{Cl}, \mathrm{C}_{6} \mathrm{H}_{4}-\mathrm{OCH}_{3}, \beta$-Naphthyl $\mathrm{R}^{2}=\mathrm{H}, \mathrm{CH}_{3}, \mathrm{NO}_{2}, \mathrm{NH}_{2}$

\subsection{Benzothietes by Cycloaddition Reactions}

A relatively new synthesis of benzothietes is based on [2+2] cycloaddition reactions of 1,2-didehydrobenzene (41a) and thiocarbonyl compounds. Whereas the reaction of 41a, obtained from o-benzenediazonium carboxylate and thiophosgene led to 2,2-dichlorobenzothiete among a vast 
mixture of products [76], the reaction of 41a and sterically hindered and/or electronically stabilized thioketones 87a-d [77,78] or 90 [77] is reasonably efficient (Scheme 20).

Scheme 20. Reaction of 1,2-didehydrobenzene and thioketones.

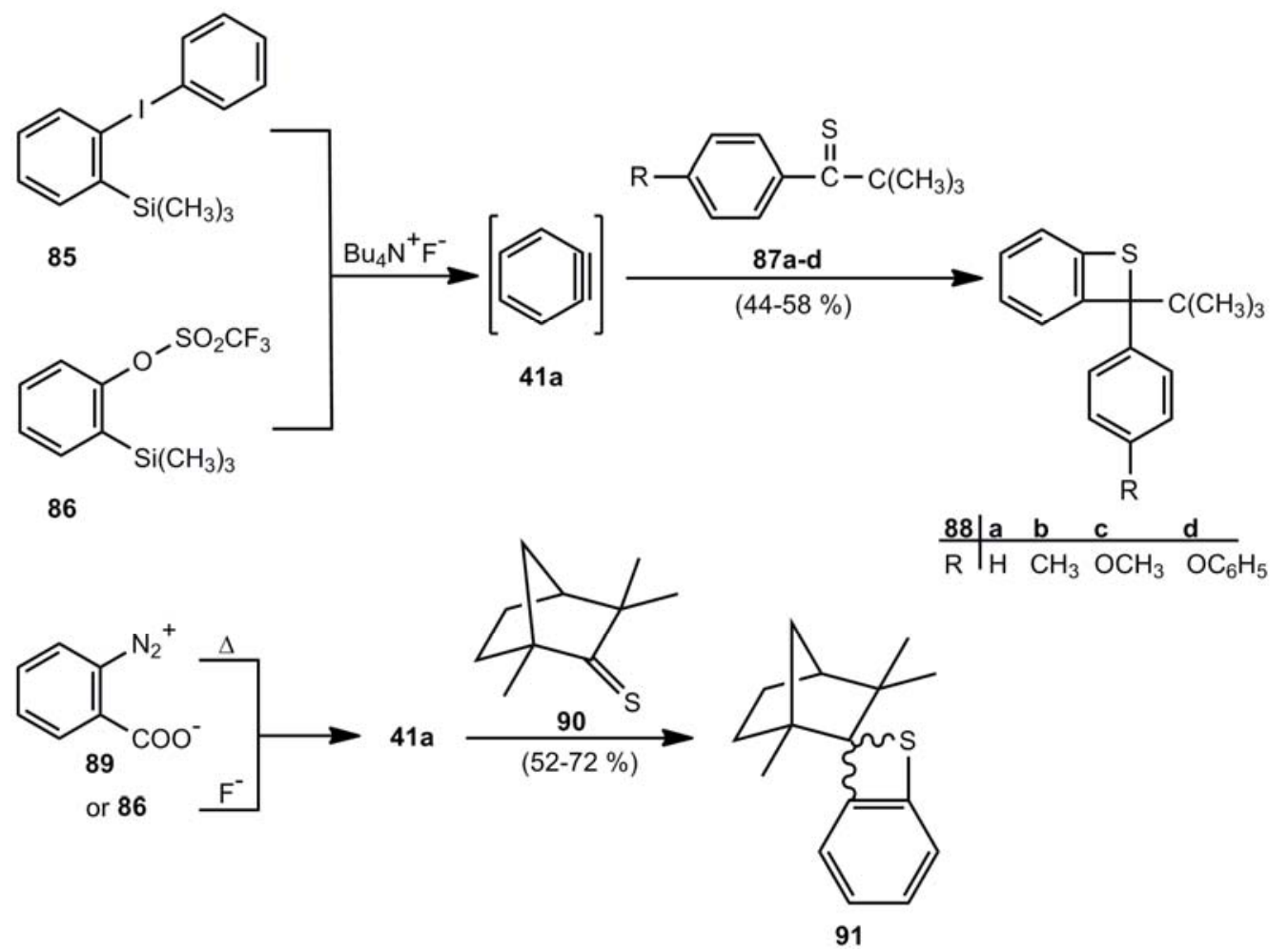

The benzothietes 88a-d are racemates, but thiofenchone (90) however, gives the diastereomeric cycloadducts $\mathbf{9 1}$. The components show a ratio of 7:1 in favor of the system with $\mathrm{S}$ in exo-position [77].

\subsection{Synthetic Applications of Benzothietes}

In contrast to the less stable benzoxetes, benzothietes are very useful for the preparation of S-heterocycles and benzene derivatives with SR groups. Two important reaction types have to be mentioned here, namely the cycloaddition of the corresponding thioquinone methides 4 as $8 \pi$ components with $2 \pi$ (or $4 \pi$ ) components and the addition of nucleophiles to 4 (Scheme 21 ).

Scheme 21. Addition and cycloaddition reactions of benzothiete/o-thioquinone methide.<smiles>c1ccc2c(c1)CS2</smiles>

3

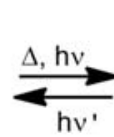

hv'

$$
\text { . }
$$<smiles>C=C1C=CC=CC1=S</smiles>

4

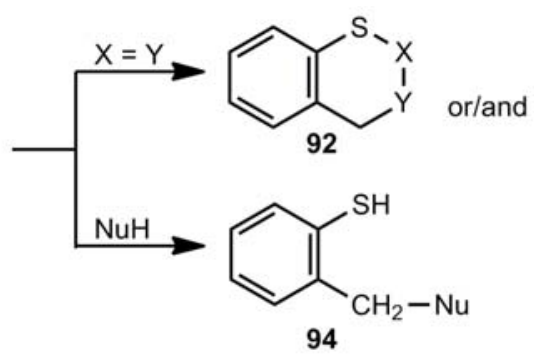<smiles>[X]Cc1ccccc1S[Tl]</smiles>

Table 2 gives a survey over the $[8 \pi+2 \pi]$ and $[8 \pi+8 \pi]$ cycloadditions of benzothiete (3) leading to the heterocyclic scaffolds 95-110. 
Table 2. $[8 \pi+2 \pi]$ - and $[8 \pi+8 \pi]$ Cycloaddition reactions of benzothietes.

[2 $\pi / 8 \pi]$
$\mathrm{C}=\mathrm{C}$
Alkenes

Benzo[c]furans

$\mathrm{C} \equiv \mathrm{C}$

Alkynes<smiles>O=C1C=CC(=O)C=C1</smiles>

1,4-Quinones (Oxidation) $\mathrm{C}=\mathrm{N}$

Azomethines

Azines

Ketenimines

Carbodiimides

Oximes and their O-derivatives

$\mathrm{C}=\mathrm{O}$

Carbonyl Compounds

$$
\mathrm{C}=\mathrm{S}
$$

Thiocarbonyl Compounds

$\mathrm{C} \equiv \mathrm{N}$

Nitriles

$\mathrm{N}=\mathrm{C}=\mathrm{S}$

Isothiocyanates

$\mathrm{N}=\mathrm{N}$

Azo Compounds

$\mathrm{N}=\mathrm{O}$

Nitroso Compounds

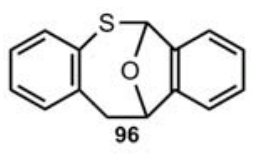<smiles>[c-]1cccc2c1SC=CC2</smiles><smiles>O=C1C=CC(=O)C2=C1[CH]c1ccccc1S2</smiles><smiles>CN1CSc2ccccc2C1</smiles>

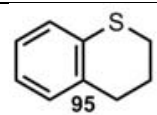<smiles>c1ccc2c(c1)CSCS2</smiles><smiles>CN1Cc2ccccc2SC1=S</smiles><smiles>CN1Cc2ccccc2SN1C</smiles>

3,4-Dihydro- $2 \mathrm{H}$ -

benzothiopyran

(Thiochroman)

$$
\text { (Thections }
$$

$[14,63,79-84]$

11,12-Dihydro-6,11-epoxy-6Hdibenzo $[b, f]$ thiocine

4H-1-Benzothiopyran (4H-Thiochromen)

9H-Thioxanthene-1,4dione

3,4-Dihydro-2H-1,3benzothiazine

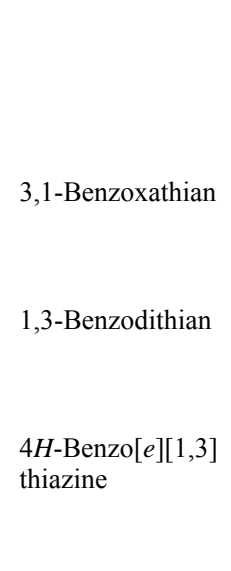

2-Imino-4H-1,3Benzodithiin

3,4-Dihydro-2H-1,3Benzothiazine-2-thione

3,4-Dihydro- $2 \mathrm{H}$ -

1,2,3-benzothiadiazine

3,1,2-Benzoxathiazine

2,3-Dihydro-1,2-benzo= thiazol-1-oxide

3,1-Benzoxathian-2carbonitrile 
Table 2. Cont.

\begin{tabular}{llll}
\hline$[2 \pi / 8 \pi]$ Components & References \\
$\substack{\mathrm{N}-\text { Sulfinylamines } \\
\mathrm{P}=\mathrm{S}}$ \\
Lawesson`s reagent
\end{tabular}

The reactivity and the regio- and stereoselectivity of all these reactions have been discussed in detail $[3,93]$. Finally the cycloaddition of benzothiete and fullerene $\mathrm{C}_{60}$ shall be mentioned. The monoadduct 95a is generated in a yield of 54\% [94] (Figure 5).

Figure 5. Adduct of benzothiete and fullerene $\mathrm{C}_{60}$.

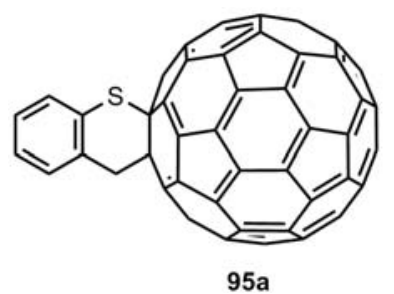

In addition to the formation of six- and eight-membered rings, five-, seven-, nine- and elevenmembered heterocycles 111-122 and macrocyclic systems 123, 124 (Figure 6) can be synthesized by applying benzothietes.

Figure 6. Further sulfur-heterocycles, which can be obtained from benzothiete.

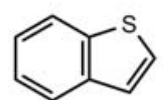

$111[3,83]$<smiles>O=S1OCc2ccccc21</smiles>

115 [92]<smiles>c1ccc2c(c1)CCS2</smiles>

112 [83]<smiles>C1=CSc2ccccc2C=C1</smiles>

116 [3]<smiles>CN1Cc2ccccc2S1</smiles>

$113[87,95]$<smiles>C1=CSc2ccccc2CC1</smiles>

$117[3,83]$

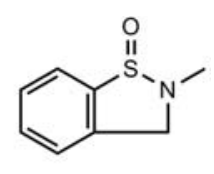

114 [92]<smiles>C1=CSc2ccccc2CO1</smiles>

118 [83]<smiles></smiles>

119 [84]<smiles></smiles>

120 [94]<smiles>CP(=O)(Cc1ccccc1SCc1ccccc1SCON)OCCO</smiles>

$123[96,97]$<smiles>COP(C)(=O)COCc1ccccc1CSc1ccccc1C</smiles><smiles>CN1CCSc2ccccc2CSc2ccccc2C1</smiles>

122 [81]

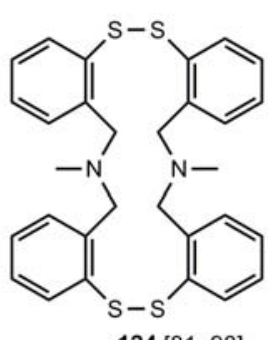

124 [81, 98] 
Dimerization of benzothiete $\mathbf{3} \rightleftarrows \mathbf{4} \rightarrow \mathbf{1 0}$ competes in all these reactions of $\mathbf{3}$ with dienophiles and nucleophiles. The less reactive the reaction partner is, the higher is the amount of $\mathbf{1 0}$. However, the portion of $\mathbf{1 0}$ is not completely lost, because FVP of $\mathbf{1 0}$ can lead back to $\mathbf{3}$.

\section{Conclusions}

Benzoxetes 1 and benzothietes $\mathbf{3}$ seem to be very similar compounds. Both have low activation barriers for the opening of the four-membered rings, but the thermal equilibrium is for the benzoxetes (1) on the side of the $o$-quinone methides 2, whereas it is for the $o$-thioquinone methides $\mathbf{4}$ on the side of the benzothietes 3 .

The different energetic situation has far-reaching consequences for the preparation of these compounds and their applications. Very few examples of substituted benzoxetes $\mathbf{1}$ have been obtained by photochemical reactions at low temperatures. The number of questionable or erroneous benzoxete structures is surprisingly high. It is much easier to generate and apply their open valence isomers, the o-quinone methides 2 [99]. The benzothietes 3, on the other hand, can be prepared by various reactions including ring contractions, cycloeliminations, cyclizations and cycloadditions. The simple access to benzothietes 3 and their high reactivity in addition and cycloaddition reactions offers a variety of applications in the synthesis of benzo-condensed $S$-heterocycles (5- to 11-membered rings and macrocycles). Table 2 summarizes for example the access to 14 different heterocyclic 6-ring systems. Another promising application can be based on the optical switching $3 \rightleftarrows 4$. Photokinetical studies [100] encourage such an application.

\section{References and Notes}

1. Tomioka, H.; Matsushita, T. Benzoxetene. Direct observation and theoretical studies. Chem. Lett. 1997, 26, 399-400.

2. Kolshorn, H.; Meier, H. EHT calculations of valence isomerization between benzenoids and o-quinoidal systems. Z. Naturforsch. 1977, 32A, 780-782.

3. Meier, H.; Mayer, A.; Gröschl, D. Benzothietes-Versatile synthons for the preparation of heterocycles. Sulfur Rep. 1994, 16, 23-56.

4. Eckes, H.-L. Nucleophilic addition and cycloaddition reactions of benzothiete. Doctoral Dissertation, University of Mainz, Mainz, Germany, 1990.

5. Arumugam, S.; Popik, V.V. Photochemical generation and the reactivity of $o$-naphthoquinone methides in aqueous solutions. J. Am. Chem. Soc. 2009, 131, 11892-11899.

6. Shanks, D.; Frisell, H.; Ottoson, H.; Engman, L. Design principles for $\alpha$-tocopherol analogues. Org. Biomol. Chem. 2006, 4, 846-852.

7. Latulle, M.; Guenot, P.; Ripoll, J.-L. The syntheses of 6-methylene-2,4-cyclohexadien-1-imine and related $o$-quinonoids by FVT of 1-hetero-1,2,3,4-tetrahydronaphthalenes. Tetrahedron Lett. 1991, 32, 2013-2016.

8. Quiao, G.G.H.; Lenghaus, K.; Solomon, D.H.; Reisinger, A.; Bytheway, I.; Wentrup, C. 4,6-Dimethyl-o-quinone methide and 4,6-dimethylbenzoxete. J. Org. Chem. 1998, 63, 9806-9811. 
9. Mao, Y.-L.; Boekelheide, V. Benzocyclobutene-o-Xylylene valence tautomerization: Oxygen and sulfur analogs. Proc. Natl. Acad. Sci. USA 1980, 77, 1732-1735.

10. Cavitt, S.B.; Sarrafizadeh, H.; Gardner, P.D. The structure of $o$-quinone methide trimer. J. Org. Chem. 1962, 27, 1211-1216.

11. Faure, R.; Thomas-David, G.; Bartnik, R.; Cebulska, Z.; Graca, E.; Lasniak, S. Tetramer of o-methylenequinone. Bull. Soc. Chim. France 1991, 378-380.

12. Adam, W.; Hadjiarapoglou, L.; Peters, K.; Sauter, M. Dimethyldioxirane epoxidation of benzofurans: reversible thermal and photochemical valence isomerization between benzofuran epoxides, quinone methides, and benzoxetenes. J. Am. Chem. Soc. 1993, 115, 8603-8608.

13. Van Tilborg, W.J.M.; Plomp, R. Flash vapor-phase pyrolysis of thiophene 1,1-dioxides. Recl. Trav. Chim. Pays-Bas 1977, 96, 282-286.

14. Kanakarajan, K.; Meier, H. Cycloaddition reactions of benzothiete. J. Org. Chem. 1983, 48, 881-883.

15. Van Tilborg, W.J.M.; Plomp, R. Synthesis of benzothiete from benzo[b]thiophene 1,1-dioxide. J. Chem. Soc. Chem. Commun. 1977, 130-131.

16. Adam, W.; Sauter, M.; Zuenkler, C. Preparation of $2 H$-benzoxetes by photoinduced [2+2] cyclo addition of quinone methides, accessible by dimethyldioxirane (DMD) oxidation of 2,3-dimethyl benzofurans. Chem. Ber. 1994, 127, 1115-1118.

17. Zhang, Q.; Liu, X.-T.; Liang, J.-Y.; Min, Z.-D. Chemical constituents from the stem of Caesalpinia decapetala. Zhongguo Tianran Yaowu 2008, 6, 168-171.

18. See also the natural product discussed in references [19] and [20].

19. Guo, S.; Tang, Y.P.; Duan, J.A.; Su, S.L.; Ding, A.W. Two new terpenoids from fruits of Ziziphus jujuba. Chinese Chem. Lett. 2009, 20, 197-200.

20. Chen, H.-L.; Wang, L.-W.; Su, H.-J.; Wie, B.-L.; Yang, S.-Z.; Lin, C.-N. New terpenoids from amentotaxus formosana. Org. Lett. 2006, 8, 753-756.

21. Tomioka, H. Matrix isolation study of reactive $o$-quinoid compounds: Generation, detection and reactions. Pure Appl. Chem. 1997, 69, 837-840.

22. Felix, D.; Winter, C.; Eschenmoser, A. Fragmentation of $\alpha, \beta$-epoxyketones to acetylenic aldehydes and ketones: Preparation of 2,3-epoxycyclohexanone and its fragmentation to 5-hexynal. Org. Synth. Coll. Vol. 1988, 6, 679-682.

23. Chapman, O.L.; Chang, C.C.; Kolc, J.; Rosenquist, N.R.; Tomioko, H. Photochemical method for the introduction of strained multiple bonds. Benzyne $\mathrm{C} \equiv \mathrm{C}$ stretch. J. Am. Chem. Soc. 1975, 97, $6586-6588$.

24. Chiang, Y.; Gaplovsky, M.; Kresge, A.J.; Leung, K.H.; Ley, C.; Mac, M.; Persy, G.; Phillips, D.L.; Popik, V.V.; Roedig, C.; Wirz, J.; Zhu, Y. Photoreactions of 3-diazo-3H-benzofuran-2-one; dimerization and hydrolysis of its primary photoproduct, a quinonoid cumulenone: A study by time-resolved optical and infrared spectroscopy. J. Am. Chem. Soc. 2003, 125, 12872-12880.

25. Voigt, E.; Meier, H. About the photochemistry of heteroanalogue 3-diazo-2-oxoindanes. Chem. Ber. 1977, 110, 2242-2248.

26. Yoshioka, E.; Kohtani, S.; Miyabe, H. A multicomponent coupling reaction induced by insertion of arynes into the $\mathrm{C}=\mathrm{O}$ bond of formamide. Angew. Chem. Int. Ed. 2011, 50, 6638-6642. 
27. Yoshioko, E.; Kohtani, S.; Miyabe, H. Sequential reaction of arynes via insertion into the $\pi$ - bond of amides and trapping reaction with dialkylzincs. Org. Lett. 2010, 12, 1956-1959.

28. Heaney, H.; McCarty, C.T. Reactions of arynes with carbonyl compounds. J. Chem. Soc. D Chem. Commun. 1970, 123.

29. Heany, H.; Jablonski, J.M.; McCarty, C.T. Aryne chemistry. XXXI. Reactions of arynes with $\alpha, \beta$-unsaturated aldehydes. J. Chem. Soc. Perkin Trans. 1 1972, 2903-2910.

30. Rayne, S.; Sasaki, R.; Wan, P. Photochemical rearrangement of dibenzo[1,4]dioxins proceeds through reactive spirocyclohexadienone and biphenylquinone intermediates. Photochem. Photobiol. Sci. 2005, 4, 876-886.

31. Müller, E.; Mayer, R.; Narr, B.; Rieker, A.; Scheffler, K. Oxygen radicals. XVII. Dehydrogenation of bisphenols under formation of ,inner“ spirocyclic quinol ethers. Liebigs Ann. Chem. 1961, 645, 25-35.

32. Müller, E.; Kaufmann, H.; Rieker, A. Synthesis of higher molecular weight compounds by phenol dehydrogenation. I. Oxidative trimerization of 4-methoxy-2,5-di-tert-butylphenol. Liebigs Ann. Chem. 1964, 671, 61-70.

33. Hewgill, F.R.; Kennedy, B.R. Oxidation of alkoxy phenols. VI. A hemiacetal from 4-methoxy-2tert-butylphenol. J. Chem. Soc. C 1966, 362-366.

34. Hewgill, F.R.; Hewitt, D.G. Oxidation of alkoxyphenols. X. The reaction of 2,2'-dihydroxy- 5,5'dimethoxy-3,3'-di-tert-butylbiphenyl with lead tetraacetate. J. Chem. Soc. C 1967, 8, 726-730.

35. Karpov, V.V.; Puchkov, V.A.; Khidekel, M.L. Synthesis of spirocyclic trimers by the oxidative coupling of phenols in the presence of complex catalysts. Zhurnal Org. Khim. 1968, 4, 1594-1603.

36. Karpov, V.V.; Khidekel, M.L. Oxidative di- and trimerization during the oxidation of phenols by oxygen in the presence of copper-containing complexes. Zhurnal Org. Khim. 1968, 4, 861-869.

37. Bowman, D.F.; Hewgill, F.R. Radical coupling in the reaction of o-halophenols with base. Chem. Commun. 1968, 524-525.

38. Hewitt, D.G. Phenol oxidation mechanism. Search for phenoxylium intermediates. J. Chem. Soc. C 1971, 1750-1757.

39. Claus, P.; Schilling, P.; Gratzl, J.S.; Kratzl, K. Preparation and oxidation of hydroxybenzyl alcohols. Monatsh. Chem. 1972, 103, 1178-1193.

40. Becker, H.D.; Gustafsson, K. Formation and photochemical isomerization of arylated 1,3dihydro-2H-azepin-2-ones. Tetrahedron Lett. 1976, 17, 1705-1708.

41. Becker, H.D.; Gustafsson, K. On the formation of spiro-substituted benzoxetes by phenol oxidation: preparation and valence isomerization of 3,3'-di-tert-butyl-5,5'-ditrityl-2,2'-dipheno quinone. Tetrahedron Lett. 1976, 17, 4883-4886.

42. Becker, H.D.; Gustafsson, K. Nucleophilic addition of amines to benzo-substituted oxetenes. Formation of 6-amino-2,4-cyclohexadienones and their ring expansion. J. Org. Chem. 1977, 42, 2966-2973.

43. Oleinik, E.P.; Mamysheva, O.N.; Gorbunova, L.V. Characteristics of reactions of shielded germanium-containing phenols in the presence of oxygen under one-electron oxidation conditions. Doklady Akad. Nauk SSSR 1986, 289, 1137-1139. 
44. Jamois, D.; Tessier, M.; Marechal, E. Preparation of amphiphilic polyisobutylenes- $\beta$-polyethylen amines by Mannich reaction. II. Study of Mannich reaction on model systems. J. Polym. Sci. A 1993, 31, 1941-1958.

45. Müller, E.; Rieker, A. Chemistry Department, University of Tübingen, Germany, unpublished work.

46. Baltes, J.; Volbert, F. Mechanism of antioxidant action. II. 3,3'-Di-tert-butyl-5,5'-dimethoxybi phenyl-2,2'-peroxide, a dehydrogenation product of 2-tert-butyl-4-methoxyphenol and its rearrangement to bis[4-methoxy-6-tert-butylbenzene-(2)]indigo. Seifen Anstrichmittel 1955, 57, 660-666.

47. Meier, H.; Schneider, H.P.; Rieker, A.; Hitchcock, P.B. Sterically hindered "benzoxetes"-the first isolated oxepins. Angew. Chem. Int. Ed. 1978, 90, 128-129; Angew. Chem. Int. Ed. Engl. 1978, 17, 121-123.

48. Schneider, H.P. Oxepines from o, $\mathrm{o}^{\prime}$-diphenoquinones, isomerization of $\alpha$-keto-o-quinone methides. Doctoral Dissertation, University of Tübingen, Tübingen, Germany, 1981.

49. See also Schneider, H.P.; Winter, W.; Rieker, A. Oxepines. Part V. The reaction of oxepino benzofurans with alcohols; the structure of Hewgill's "trialkoxyspirobenzoxetes". J. Chem. Res. Synopses 1978, 336-337.

50. Hagen, H.; Becke, F. (BASF AG) Spiro[benzoxete-2,2'-imidazolidines] and corresponding hexhydropyrimidines. Ger. Offen. DE 2034758 A 19720120, 1972.

51. Aroyan, A.A.; Iradyan, M.A. Synthesis of some tetrasubstituted ethylenediamines. Armyanskii Khimicheskii Zhurnal 1966, 19, 784-792.

52. Klosa, J. Synthesis of spasmolytically active substances. XXI. Synthesis of $\alpha$-alkoxybenzilic acid hydrazides. J. Prakt. Chem. 1966, 31, 20-33.

53. Osman, A.M.; Bassiouni, I. 2-Aryinaphthoxazoles and some other condensed oxazoles. J. Org. Chem. 1962, 27, 558-561.

54. Mastagli, P.; Metayer, M.; de Bievre-Gallin, G. Action of formamide on substituted benz aldehydes. Bull. Soc. Chim. France 1948, 662-665.

55. Von Euler, H.; Adler, E.; Cedwall, J.O. Reaction of phenols with $\mathrm{C}_{2} \mathrm{H}_{2}$. Arkiv. Kemi Mineral. Geol. 1942, 15A, 10.

56. Darapsky, A.; Berger, H.; Neuhaus, A. Action of hydrazine hydrate on lactones. J. Prakt. Chem. 1936, 147, 145-160.

57. Cox, E.H. Mechanism and application of the Fries reaction. J. Am. Chem. Soc. 1930, 52, 352-358.

58. Meier, H.; Issa, A.; Merkle, U. 5aH, 1OaH,15aH-Tribenzo[b,f,j][1,4,7]trioxa[9b]azaphenalenesalledged benzoxetes. Z. Naturforsch. 1979, 34b, 290-296.

59. Voigt, E.; Meier, H. Synthesis of the 2H-1-thiacyclobutabenzene system. Angew. Chem. 1976, 88, 94; Angew. Chem. Int. Ed. Engl. 1976, 15, 117.

60. Voigt, E.; Meier, H. Photochemistry of heteroanalogue 3-diazo-2-oxoindanes. Chem. Ber. 1977, 110, 2242-2248.

61. Raasch, M.S. Syntheses with halogen derivatives of thiophene and benzothiophene. J. Org. Chem. 1980, 45, 2151-2155. 
62. Schulz, R.; Schweig, A. Theory and application of photoelectron spectroscopy. Part 87. Elucidation of thermal reaction by variable temperature photoelectron spectroscopy. A new synthesis of benzothiete and first direct evidence for transient benzothiete ketene. Tetrahedron Lett. 1980, 21, 343-346.

63. Meier, H.; Mayer, A. Synthetic equivalents for benzo- and naphthothietes. Synthesis 1996, 1996, $327-329$.

64. Kolmakov, K.A.; Kresge, A.J. Synthesis of possible $o$-thioquinone methide precursors. Canad. J. Chem. 2008, 86, 119-123.

65. van Tilborg, W.J.M.; Plomb, R. Synthesis of benzothiete from benzo[b]thiophene 1,1-dioxide. J. Chem. Soc. Chem. Commun. 1977, 130-131.

66. van Tilborg, W.J.M.; Plomb, R. Flash vapor-phase pyrolysis of thiophene 1,1-dioxides. Recl. Trav. Chim. Pays-Bas 1977, 96, 282-286.

67. Hortmann, A.G.; Aron, A.J.; Bhattacharya, A.K. 3H-1,2-Benzodithiole oxides: Studies directed toward the generation of $o$-thiobenzoquinone methide and benzo[b]thiete. J. Org. Chem. 1978, 43, 3374-3378.

68. The pyrolysis zone can be filled with quartz particles for this purpose.

69. Davis, F.A.; Awad, S.B.; Jenkins, R.H., Jr.; Billmers, R.L.; Jenkins, L.A. Chemistry of sulfenic acids. 5. A novel rearrangement of 2,4,6-trineopentylbenzenesulfenic acid to 2-tert-butyl-4,6dineopentylbenzo[b]thiete and 3,3-dimethyl-4,4-dihydro-6,8-dineopentylbenzo[b]thiopyran. Synthesis of thiete sulfoxides. J. Org. Chem. 1983, 48, 3071-3074.

70. Pohl, E.; Herbst-Irmer, R.; Sheldrick, G.M. Structure of 4,6-bis(trifluoromethyl)-2,2-bis[2,4,6tris(trifluoromethyl)phenylthio]-1-thiabenzocyclobutene. Acta Crystallogr. C 1993, C49, 1026-1028.

71. Hagen, H.; Amann, A.; Becke, F. (BASF AG) Spiro[benzothiete-2,2'-imidazolidines] and corresponding hexahydropyrimidines. Ger. Offen. DE 2034987, 1972.

72. Hagen, H.; Amann, A.; Giertz, H. (BASF AG) 2-(o-Alkylthiophenyl)-1,3-diazocycloalkene hydrohalides. U.S. Patent 4,122,263, 1978.

73. Korobov, M.S.; Minkin, V.I.; Nivorozhkin, L.E. Benzoid-quinoid tautomerism of azomethines and their structural analogs. XX. Imines of 5-nitrothiosalicylaldehyde. Zhur. Organ. Khimii 1975, 11, 836-842.

74. Goldfarb, Y.L.; Skorova, A.E.; Kirmalova, M.L. Action of sodium in liquid ammonia on diethyl acetal of 6-methylthio-3-methylbenzaldehyde. Izv. Akad. Nauk. SSSR Seriya Khim. 1966, 1426-1432.

75. Goldfarb, Y.L.; Skorova, A.E.; Kirmalova, M.L. Action of sodium in liquid ammonia on 6methylthio-3-methylbenzaldehyde. Izv. Akad. Nauk SSSR Seriya. Khim. 1966, 1421-1425.

76. Nakayama, J.; Horikoshi, R.; Ishii, A.; Hoshino, M.; Kobayashi, H. Reaction of benzyne with thiophosgene. Phosphorus Sulfur Silicon Relat. Elem. 1983, 16, 195-199.

77. Okuma, K.; Shiki, K.; Sonoda, S.; Koga, Y.; Shioji, K.; Kitamura, T.; Fujiwara, Y.; Yokomori, Y. Reaction of electronically stabilized thiones with benzyne. The isolation of thiobenzophenonebenzyne and thiopivalophenone-benzyne adducts. Bull. Chem. Soc. Jpn. 2000, 73, 155-161.

78. Okuma, K.; Shiki, K.; Shioji, K. Reaction of thiopivalophenones with benzyne. Formation of $2 \mathrm{H}-$ benzo[b]thietes. Chem. Lett. 1998, 79-80.

79. Meier, H.; Eckes, H.-L.; Niedermann, H.-P.; Kolshorn, H. A nonspecific Diels-Alder reaction. Angew. Chem. Int. Ed. 1987, 99, 1040-1042; Angew. Chem. Int. Ed. Engl. 1987, 26, 1046-1048. 
80. Meier, H.; Schmidt, M.; Eckes, H.-L. Cycloaddition of benzothiete and 4-substituted styrenes. Chem. Ber. 1989, 122, 1545-1550.

81. Meier, H.; Saul, K.; Jacob, D. Reactions of benzothiete and imines. Liebigs Ann. Chem. 1993, 313-319.

82. Gröschl, D.; Mayer, A.; Schmidt, M.; Meier, H. Synthesis of benzo[b]thioxanthenes. J. Prakt. Chem. Chem. Ztg. 1995, 337, 379-384.

83. Meier, H.; Gröschl, D. Reaction of 2H-1-benzothiete with diazo compounds in the presence of (II) rhodium acetate. Tetrahedron Lett. 1995, 36, 6047-6050.

84. Gröschl, D.; Meier, H. Cycloaddition reactions of $2 H$-benzo[b]thiete and conjugated cyclic dienes. J. Heterocycl. Chem. 1996, 33, 1727-1729.

85. Gröschl, D.; Niedermann, H.-P.; Meier, H. Cycloadditions of $2 H$-benzo[b]thietes and compounds with cumulated double bonds. Chem. Ber. 1994, 127, 955-958.

86. Jacob, D.; Meier, H. Cycloaddition reactions of benzothiete with azomethines. J. Heterocycl. Chem. 1986, 23, 1085-1086.

87. Jacob, D.; Niedermann, H.-P.; Meier, H. Cycloaddition reactions of benzothiete and hetero dienophiles for the synthesis of heterocyclic systems. Tetrahedron 1986, 27, 5703-5706.

88. Meier, H.; Saul, K.; Mengel, R.; Niedermann, H.-P. Cycloaddition of benzothiete and oximes, oxime ethers and oxime esters. J. Heterocycl. Chem. 1991, 28, 843-848.

89. Schmidt, M.; Meier, H.; Niedermann, H.-P.; Mengel, R. 4H-3,1-Benzoxathiines from benzothiete and carbonyl compounds. Chem. Ber. 1990, 123, 1143-1148.

90. Meier, H.; Gröschl, D.; Beckert, R.; Weiß, D. Cycloaddition reaction of $2 H$-benzo[b]thiete and thiocarbonyl compounds. Liebigs Ann. 1997, 1997, 1603-1605.

91. Schmidt, M.; Meier, H.; Saleh, S.-A. Cycloaddition of benzothiete and electron-deficient nitriles. J. Heterocycl. Chem. 1991, 28, 573-575.

92. Saul, K.; Eckes, H.-L.; Jacob, D.; Meier, H. Cycloadditions of benzothiete and aromatic nitroso compounds. Chem. Ber. 1993, 126, 775-758.

93. Meier, H.; Schmidt, M.; Mayer, A.; Schollmeyer, D.; Beile, B. Stereoselective synthesis of polycyclic thiopyrans. J. Heterocycl. Chem. 2012, in press.

94. Ohmo, M.; Kojima, S.; Shirakawa, Y.; Eguchi, S. Hetero-Diels-Alder reaction of fullerene: Synthesis of thiochroman-fused C60 with $o$-thioquinone methide and oxidation to its S-oxides. Tetrahedron Lett. 1995, 36, 6899-6902.

95. Kanakarajan, K.; Meier, H. Ring enlargement of benzothiete to 2,3-dihydrobenz[d]isothiazoles. Angew. Chem. Int. Ed. 1984, 96, 220; Angew. Chem. Int. Ed. Engl. 1984, 23, 244.

96. Niedermann, H.-P.; Eckes, H.-L.; Meier, H. Reactions of benzothiete with phosphorusnucleophiles-A novel type of Arbuzov rearrangement. Tetrahedron 1989, 30, 155-158.

97. Eckes, H.-L.; Niedermann, H.-P.; Meier, H. Addition of phosphorous nucleophiles to benzothiete. Chem. Ber. 1991, 124, 377-381.

98. Meier, H. Benzothiete, a versatile reagent in heterocyclic syntheses. J. Prakt. Chem. Chem. Ztg. 1996, 338, 383-385.

99. Rokita, S.E. Quinone Methides; Wiley: San Francisco, CA, USA, 2009. 
100. Drohm, C.; Meyer, H.; Schweig, A. Kinetics of a monomolecular photoreaction in a strongly light-absorbing solid solution exemplified by the forward reaction of the optically switchable o-thiobenzoquinone methide. Chem. Phys. Lett. 1995, 245, 529-533.

(C) 2012 by the authors; licensee MDPI, Basel, Switzerland. This article is an open access article distributed under the terms and conditions of the Creative Commons Attribution license (http://creativecommons.org/licenses/by/3.0/). 